\title{
Antecedents of the Cuban Agricultural Policies of the 1990s 1
}

José Alvarez ${ }^{2}$

On October 28, 2000, U.S. President Bill Clinton signed the Trade Sanctions Reform and Export Enhancement Act (TSRA) which allowed U.S. firms to sell food and agricultural products to Cuba and other countries. However, the Cuban government did not purchase any of these products until December of 2001 following the devastating damage caused by Hurricane Michelle to important agricultural areas in November of that year.

Cuban purchases from U.S. firms amounted to $\$ 4.319$ million in 2001, \$138.635 million in 2002, and $\$ 256.9$ million in 2003. Cuba became the 35th most important food and agricultural export market for the United States in 2003, up from last (226th) in 2000. Actual purchases and pending contracts in the first-half of 2004 are at a pace to move Cuba into the top 20 most important markets of U.S. food and agricultural exports. Furthermore, because current U.S. legislation requires that all Cuban purchases from the United States must be conducted on a cash basis, the lack of credit risk associated with these sales makes Cuba one of the most attractive export markets for U.S. firms.
Anticipating changes in U.S.-Cuba trade relations, the Food and Resource Economics Department at UF/IFAS initiated a research initiative on Cuba in 1990, including a 1993 collaborative agreement with the University of Havana, which has lasted to this day. (Most of the resulting publications can be found at http://www.cubanag.ifas.ufl.edu). We reiterate that our role as investigators is to provide the best available information and analyses from which rational decisions can be made. The reports included in this series intend to address the increasing level of interest in the Cuban market for food and agricultural products among U.S. firms and to assist them in becoming more familiar with that market. The complete list of documents in this series can be found by conducting a topical search for "Cuba" at http://edis.ifas.ufl.edu, or under "Additional Information" at the end of this document.

\section{Introduction}

The three primary forces leading to the implementation of new economic policies for Cuban agriculture during the 1990s are the subject of this fact sheet. These policies were not the result of abrupt

1. This is EDIS document FE485, a publication of the Department of Food and Resource Economics, Florida Cooperative Extension Service, UF/IFAS, University of Florida, Gainesville, FL. Published July 2004. Please visit the EDIS website at http://edis.ifas.ufl.edu.

The author would like to thank the University Press of Florida (http://www.upf.com) for permission to reproduce material from the book Cuba's Agricultural Sector (Alvarez, 2004).

2. José Alvarez, Professor, Department of Food and Resource Economics, Everglades Research and Education Center, Belle Glade, FL, Florida Cooperative Extension Service, UF/IFAS, University of Florida, Gainesville, FL.

The Institute of Food and Agricultural Sciences is an equal opportunity/affirmative action employer authorized to provide research, educational information and other services only to individuals and institutions that function without regard to race, color, sex, age, handicap, or national origin. For information on obtaining other extension publications, contact your county Cooperative Extension Service office. Florida Cooperative Extension Service/Institute of Food and Agricultural Sciences/University of Florida/Christine Taylor Waddill, Dean. 
and irrational decisions by the Cuban leadership. They originated in three unrelated events that unfolded separately and almost simultaneously: (1) the relationship between state intervention and poor agricultural performance that was aggravated during the 1980s, (2) the demise of socialism in the countries of Eastern Europe and the Soviet Union, and (3) the reinforcement of U.S. economic sanctions against Cuba.

\section{State Intervention and Agricultural Performance: Looking Back at the 1970 and 1980 Decades}

The agricultural policy changes in Cuba in the 1990s reflect the need to adapt to a deteriorating economic situation. They are also an implicit recognition of the failure of previous policies that favored, for more than three decades, the development of the state farm as the preferred form of agricultural organization within the general framework of the state extensive growth model of agricultural development. Several Cuban scholars have recognized the failure of this model. For example, Nova González (1994) stated that, since 1979 or 1980 but especially since 1986, Cuba's agricultural and livestock activities in general experienced production declines, loss of efficiency, and/or stagnation in key production areas. This happened despite the strong investment process that took place in agriculture (around $30 \%$ of total investments in the country during the 1980s), the high availability of tractors, and the high use of nutrients per hectare. The result was continuing increases in productive expenses and the labor force. Furthermore, while $39 \%$ of state agricultural enterprises showed positive financial results in 1986, only $27 \%$ did so in 1990.

\section{State Versus Nonstate Production and Productivity}

The general hypothesis of this section (mostly based on Alvarez and Puerta, 1994) is that, as state intervention over agricultural production units decreases, the quantity and quality of output increases despite decreasing access to factors of production and other resources. The analyses are based upon the contribution of the nonstate sector to total production from its share of planted area and the total production per planted area-a proxy for missing yield data in all crops, except sugarcane.

Specific hypotheses are included for more perishable commodities such as vegetables; less perishable commodities such as cereals, beans, and viandas (mostly tubers and roots-cassava, sweet potato, taro, pumpkin, and yam); and intermediate commodities such as sugarcane (which needs to be processed in the state mills and for which complete data are available) and tobacco. The specific hypotheses originate in the following assumed scale of preferences for farmers, with farmers' priorities moving from left to right:

on -farm consumption $==>$ barter $==>$ black market sales

The quota for the state procurement agency (Acopio) is not included at the beginning of the scale because, rather than being a preference, it is the only means that guarantees farmers limited access to inputs.

The previous hypotheses and the way they are explored are influenced by the problems with productivity in the nonstate sector during the 1970s and 1980s (Forster, 1989, pp. 241-243), which include lack of yield statistics and incomplete statistics, excluding output consumed on the farm or bartered or sold outside official channels.

Finally, official statistics on the area planted by nonstate farmers seem to be based on the contracts negotiated by each cooperative with Acopio. It is unclear whether planted areas, as officially reported, were based on the plan or on other figures of what these various groups actually delivered to the state. Nevertheless, the fear of future expropriations and the satisfaction of their scale of preferences may have led farmers to: (a) under-report their planted area; (b) not report intercropping practices; and (c) report plantings intended for sales as self-consumption.

Those statistical problems do not preclude the fulfillment of this section's objectives. The caveats, however, should be kept in mind when reading the discussion on productivity in most of the commodities analyzed. 


\section{Sugarcane}

Sugarcane is perhaps the best case study to elucidate the validity of the main postulate of this section for the reasons stated by Forster (1989). First, because it occupies most of Cuba's farm cropland and is of critical importance to the national economy, it has been a high priority crop for state managers and technicians. Second, it is the commodity for which the most data are available. And third, because it requires processing, it is not consumed in significant amounts by nonstate producers nor sold privately in large quantities outside official channels (p. 248).

Even with the dramatic disparity of nonstate farmers' access to inputs, they have performed better than state farms in each of the 21 seasons (zafras) covering the period 1968-1969 through 1988-1989. On average, these farmers accounted for $17.9 \%$ of the harvested area but produced $19.3 \%$ of the total output. Yield differences between state and nonstate farms ranged from a low 0.3 metric tons per hectare in 1983-1984 to a high 11.7 metric tons per hectare in 1976-1977. Average yields in the nonstate sector over the 21-year period were 54.8 metric tons per hectare, compared with 50.0 metric tons per hectare in the state sector, with both following almost identical patterns which may reflect annual weather conditions. These figures represent an average difference of around five metric tons per hectare, per year, which translate into an advantage of close to $10 \%$ in favor of the nonstate sector. These results may appear fairly insignificant but, under land tenure conditions present until 1989, they represented an "extra" zafra (sugar season) every 10 years (Alvarez and Puerta, 1994).

In summary, the case of sugarcane supports the main hypothesis of this section. Until 1989, the nonstate sector was more productive than the state sector in the case of an intermediate commodity (such as sugarcane) despite the lack of access by the nonstate sector to some capital inputs and technology. Almost all sugarcane produced is delivered to Acopio because it is not suitable for direct consumption, bartering, or black market sales since it needs to be processed and the state controls all sugar factories.

\section{Seasonal Crops}

It is more difficult to prove the general hypothesis in the case of seasonal crops because the lack of data restricts the analysis. The information that is available suggests that the performance of the nonstate sector in the production of seasonal crops has been mixed.

\section{Tubers and Roots}

With the exception of potato, the contribution of the nonstate sector to total production of tubers and roots is smaller than its share of the area planted to these crops because of lower production per planted area. During the study period (1970, 1975, and 1977-1989), the annual average share of area planted to potato by the nonstate sector was almost $18 \%$, while its contribution to total production per year was over $19 \%$.

The figures for other tubers and roots show a different picture. Average annual share of area planted to sweet potato by the nonstate sector was $34.6 \%$, while average annual contribution to production was $30 \%$, reflecting the difference in production per planted area between 3.9 and 3.3 metric tons per hectare for the state and nonstate sectors, respectively. Taro shows more dramatic differences than sweet potato. While the average share of planted area for the nonstate sector amounted to $55 \%$, the nonstate sector contributed only $34.5 \%$ to total production per year as the result of an annual average 8.6 metric tons per hectare in the state sector versus an average 3.2 metric tons per hectare in the nonstate sector. Statistics for all tubers and roots (which include other crops also) show a nonstate average share of planted area of $40 \%$, with a $29 \%$ contribution to total production. Average annual production per planted area was higher (6.5 metric tons per hectare) in the state sector than the 3.9 metric tons per hectare of the nonstate sector.

The low degree of perishability of these commodities, combined with the assumed scale of preferences for farmers, may provide an explanation for the apparent low performance of the nonstate sector. Tubers and roots can be stored for a period of time long enough to permit hiding them from Acopio for future on-farm consumption, bartering, or sales in 
the black market. The case of taro, which reflects the poorest performance, may illustrate the previous explanation. Cuban consumers have a high preference for taro, and therefore the demand for this commodity is higher than that for other tubers and roots. This commodity is not legally available to the general population since it is allocated through rationing primarily to groups with special diets (e.g., small children, the elderly, and people with digestive problems).

\section{Vegetables}

The nonstate sector has consistently produced more than its share of area planted to these crops. During the study period, the nonstate sector accounted for an average of $49 \%$ of the area planted to all vegetables, while its contribution to total vegetable production averaged $60 \%$. Specific figures for tomato are 54\% and 58\%; for onion, $42 \%$ and $49 \%$; and for pepper, $76 \%$ and $89 \%$, respectively. The differences in annual average production per planted area are impressive when one considers the constraints faced by farmers in the nonstate sector. On average, the nonstate sector has outproduced the state sector in tomato $(17.5 \%)$, onion (38\%), pepper (116\%), and all combined vegetables $(56 \%)$ in each of the 16 years in the study period.

The main hypothesis of this section is supported in the case of vegetables. The reason for the higher apparent productivity in the nonstate sector than was the case for tubers and roots may be the fact that these highly perishable crops have to be moved quickly to the state's refrigerated facilities to avoid spoiling. For that reason, they are less likely than tubers and roots to be held in large quantities for consumption on the farm, bartering, or black market sales. Therefore, vegetable statistics (as sugarcane statistics) are likely closer to actual production than those of less perishable crops.

\section{Cereals}

Cereals present a different picture than the extremes portrayed by the two previous groups of commodities during the study period. In rice, the nonstate sector contributed slightly less to total output $(8.5 \%)$ than its share of area planted $(9.9 \%)$ because of higher production per planted area in the state sector (3.1 metric tons per hectare) than in the nonstate sector (2.6 metric tons per hectare). At first, it was thought that these Acopio figures could be very close to real output since farmers lack drying, storing, and milling facilities that would enable them to consume, barter, or sell rice outside official channels. Lack of inputs (especially irrigation facilities, fertilizers, and chemicals) could be responsible for the slightly lower production reported for the nonstate sector. Statements made by researchers at Cuba's Rice Research Institute (IIA), however, add unequivocal support to the hypothesis concerning rice and also to the existence of the farmers' scale of preferences. According to Socorro et al. (2001, p. 111), the per capita consumption of rice is highest among the rural and peasant populations who are regular producers and who plant rice fundamentally to satisfy their own family needs. And they add: "the per capita consumption of this population cannot be less than twice the one reported in the official statistics" (p. 111).

Corn production statistics reveal higher figures for the state sector. While the nonstate sector's share of planted area to corn is over $50 \%$, it only produced $38 \%$ of the total output, with the state sector showing yields of 0.6 metric tons per hectare versus 0.3 metric tons per hectare in the nonstate sector. The lower average production figures in corn by the nonstate sector may be the result of farmers' scale of preferences since corn can be stored for long periods of time without spoiling. Farmers mainly sell corn for human consumption as on-the-cob and as corn meal. An additional factor that may explain the differences is the fact that corn is also used as animal feed and farmers may divert additional amounts for that purpose.

\section{Beans}

With an average share of planted area of $43.6 \%$ during the study period, the nonstate sector contributed an average of $33 \%$ to total annual bean production. Average production per planted hectare amounted to 0.3 metric tons per hectare in the state sector versus 0.2 metric tons per hectare in the nonstate sector. Beans are another good example of farmers' scale of preferences: they are a Cuban staple and can be stored for long periods of time. 


\section{Tobacco}

During the study period, the nonstate sector averaged over $73 \%$ of planted area while contributing an average of over $74 \%$ to total annual tobacco production. This corresponds to average production per planted area of 0.6 and 0.7 metric tons per hectare in the state and nonstate sectors, respectively.

Tobacco is another crop that supports the main hypothesis of this section. First, as is the case with sugar, this is an important export crop that receives special attention by state managers and technicians. Second, there are large numbers of tobacco Agricultural Production Cooperatives in the nonstate sector with better access to inputs and technical assistance than the Cooperatives of Credit and Services and dispersed farmers. Third, this crop needs further processing, and thus farmers would be expected to transfer most of their production to the state procurement agency. Fourth, Acopio prices for tobacco have been generally higher relative to other crops partly due to the state's interest in promoting a hard currency export product. Therefore, the results are very similar to those obtained in sugarcane in terms of higher productivity in the nonstate sector.

\section{The Free Farmers' Markets of the 1980s}

The free farmers' markets (Mercado Libre Campesino, MLC) of the 1980s tend to support the general and specific hypotheses of this fact sheet. Less state intervention had a positive impact on the quantity, quality, and variety of food produced outside the state sector. The quick response of farmers showed their ability to increase their production in response to market incentives. The dismal performance of the state agricultural sector made it unable to meet its obligation to consumers. To a large extent, however, the portion of production by the nonstate sector transferred to the state's procurement system allowed the government to distribute rationed quotas to consumers. Only the remaining production was available for sell in the MLCs - a fact not sufficiently emphasized in the literature. Lessons learned from the MLC experience included:

- before their establishment, nonstate farmers were outproducing state farms in many commodities, but most of their production was consumed on the farm, bartered, or sold in the black market.

- given the right incentives, nonstate farmers could produce more despite their limited access to inputs.

- lack of transportation and containers did not impede the flow of goods to the MLCs.

- the black market became almost obsolete when prices and sales were freed.

- a latent entrepreneurial spirit surfaced with the proliferation of "middle men" providing storage and ancillary services to farmers attempting to access the MLCs.

\section{Income Disparities}

Research has shown direct evidence about differences in productivity between the state and nonstate sectors and disparities in income levels among farm workers of different agricultural organizations, which seems to indicate differences in productivity. The results come from field research conducted in three municipalities of western, central, and eastern Cuba.

Peasant households generate the highest income levels in the agricultural sector. Moreover, private sector incomes were considerably higher than those of households of state farm workers (Deere et al., 1995). According to these researchers, the relatively high incomes earned by members of Agricultural Production Cooperatives (CPAs) are indicative of the higher profitability and productivity of Cuba's production cooperatives, compared to the state farms (p. 231).

\section{The Food Program}

The dismal performance of the state agricultural sector, when evaluated against its high capital investments and high use of modern inputs, was evident to state planners by the 1980s. By the beginning of the 1990s it became apparent that something dramatic had to be done. The Food Program (Plan Alimentario, PA) was the last attempt by the Cuban leadership to solve Cuba's food problem through central planning. Although this plan 
dates back to the mid-1980s, following the closing of the free farmers' markets, it increased in importance after the establishment of the "Special Period in Time of Peace" in mid-September of 1990.

Enríquez (1994) stated that "the Food Program has subsequently come to represent one of the-if not the-most important areas of government initiative in Cuba today. Without exaggeration, the food issue will play a key role in determining the future course of social change in socialist Cuba" (p. 1).

The general goal of the Food Program was to make Cuba self-sufficient in most agricultural commodities. Enríquez (1994, p. 23) mentions several measures that were to be undertaken to ensure that the program would succeed: (1) significant expansion in the areas planted; (2) higher levels of technology such as mechanization, irrigation, and improved seed varieties; and (3) the mobilization of tens of thousands of people to work in the food crop sector on either a temporary or permanent basis. An additional effort would be made to encourage replacement in the national diet of certain imported food items by locally grown products.

The PA was another example of what Cubans call gigantism, a word used throughout the years to denote the huge (giant) amount of resources devoted to each task (e.g., trying to solve the lack of labor became a monumental task). Enríquez describes how the major mobilizations took place, how dozens of labor camps were established, and even how 40 new communities were planned in the countryside to house the worker "contingents." These communities would offer housing, stores, health care centers, day care, schools, swimming pools, etc. (1994, pp. 27-28).

The heavy capital investment in the PA did not produce the expected results. After initial mixed results and facing increasing labor and input shortages, the PA was abandoned around 1993. The failure of the PA was implicitly recognized around the same time as the crumbling of socialism in Eastern Europe. This historic event would result in drastic negative impacts on the Cuban economy in general and in the agricultural sector in particular.

\section{The Demise of Socialism in Eastern Europe and the Soviet Union}

The disappearance of the Soviet bloc and the Council for Mutual Economic Assistance (CMEA) at the end of the 1980s represented the elimination of the main framework within which Cuba's economic relations were taking place. At the end of the 1980s, Cuba was conducting $81 \%$ of its external commercial relations with the other CMEA member countries (Soviet Union, Bulgaria, Czechoslovakia, East Germany, Hungary, Poland, Mongolia, and Vietnam). This group of countries received the bulk of Cuba's total exports (63\% sugar, $73 \%$ nickel, and $95 \%$ citrus) and was the source of about $85 \%$ of Cuba's total imports, including $63 \%$ food, $86 \%$ raw materials, $98 \%$ fuels and lubricants, $80 \%$ machinery and equipment, and 57\% chemical products (Alvarez González and Fernández Mayo, 1992, pp. 4-5). Furthermore, trade relations between the CMEA and Cuba took place under favorable conditions for the Cuban economy. It has been estimated that during the 1981-1990 period, Cuba received export revenues over $50 \%$ higher than if it had sold its exports at world market prices (Alvarez González and Fernández Mayo, 1992, p. 4).

The direct impact that the demise of the CMEA had on the Cuban economy becomes obvious when analyzing Cuban import statistics for 1989 and 1992. In 1989, Cuban imports exceeded eight billion pesos. By 1992, it had declined to two billion pesos, for a decrease in value of about $75 \%$ in only three years (Alvarez González and Fernández Mayo, 1992, p. 8).

A reduction of such magnitude in both imports and exports necessarily and severely impacts the economic and social activity of any country. The living standard of the general populace in Cuba has deteriorated since the beginning of the "Special Period" in mid-September of 1990. As the economic crisis unfolded, food availability in the ration stores continually worsened. Oil shortages for power generation grew so critical that rolling power blackouts became a regular part of life throughout the country. Gasoline and spare parts for automobiles and buses became so scarce that a large proportion of the population was relegated to using bicycles as their 
primary means of transportation. Shortages of inputs, such as fuel, lubricants, and spare parts, impacted the whole economy. Agricultural inputs and equipment experienced severe restrictions because of the decline in imports, including potassium chloride, ammonia, herbicides, potassium sulfate, ammonium sulfate, triple superphosphate, urea, loaders, irrigation motors, agricultural tools, towing equipment, crawler tractors, and tractors with rubber tires. Castro referred to this situation in a peculiar way while addressing a congress of Cuban agricultural workers. He lamented that, "our former allies have left us high and dry (nos han dado una embarcada), comrades, to say it in plain language" (Granma, November 26, 1991, p. 5).

This external shock to the Cuban economy aggravated the situation created by the inefficiency inherent in the state agricultural model. The next blow also came from abroad - this time from the United States.

\section{The Reinforcement of the U.S. Economic Sanctions}

The demise of socialism in Eastern Europe and the Soviet Union increased the influence of the most conservative sectors of the United States in the design of U.S. policy toward Cuba. That event reinforced their belief that strengthening economic sanctions against Cuba would accelerate the fall of the Castro regime.

The new policy approach, however, was implemented in two phases. Recall that, in 1975, President Ford had amended the regulation of economic sanctions against Cuba to allow U.S. companies to trade with the island through subsidiaries located in third-party countries. The drying up of trade with Eastern Europe brought about a sharp increase in this type of trade. License applications to the U.S. Treasury Department for sales to Cuba by foreign subsidiaries of U.S. firms almost tripled from \$246 million in 1988 to $\$ 718$ million in 1992 (Kaplowitz and Kaplowitz, 1993, p. 232).

In 1989, Senator Connie Mack (R-FL) introduced an amendment in the U.S. Congress that essentially would prevent U.S. subsidiary trade with Cuba. Allies and trade partners of the United States said they would refuse to comply with what they considered to be an extraterritorial legislation. Such was also the thinking of the U.S. Department of State. Finally, in 1991, President Bush vetoed the Export Administration Act, which contained the Mack Amendment (Kaplowitz and Kaplowitz, 1993, pp. 234, 235).

In April of 1992, President Bush signed an executive order prohibiting ships transporting merchandise or persons to or from Cuba to arrive at U.S. ports in the following 180 days. In October of 1992, the U.S. Congress passed the so-called Cuban Democracy Act, better known as the Torricelli Bill. The law reiterated the prohibition against U.S. firms having economic relations with Cuba and extended the prohibition to their subsidiaries in third-party countries. It also encouraged other countries to enact similar measures. Four years later, in March of 1996, the U.S. Congress passed, and President Clinton signed into law, the well-known Helms-Burton Bill (Roy, 2000), which reinforced current economic sanctions and added new ones to the embargo.

\section{Conclusions and Implications}

This fact sheet has discussed what appear to have been the three main reasons leading to Cuba's economic policies of the 1990s. They included the inefficiency of the state agricultural sector, the demise of socialism in Eastern Europe, and the tightening of U.S. economic sanctions against Cuba.

The Cuban leadership had to finally come to terms with reality. The three processes discussed above led them back to the drawing board. On July 26, 1993, only nine months after the enactment of the Torricelli Bill, Castro announced that Cuba was initiating a process of implementing new economic policies.

\section{References}

Alvarez, José. 2004. Cuba's Agricultural Sector. Gainesville, FL: University Press of Florida.

Alvarez, José and Ricardo A. Puerta. 1994. State Intervention and Cuban Agriculture: Impact on Organization and Performance. World Development 12 (11): 1663-1675. 
Alvarez González, Elena, and María Antonia Fernández Mayo. 1992. Dependencia Externa de la Economía Cubana. In Documento INIE. Ciudad de la Habana: Instituto de Investigaciones Económicas.

Deere, Carmen Diana, Ernel González, Niurka Pérez, and Gustavo Rodríguez. 1995. Household Incomes in Cuban Agriculture: A Comparison of State, Co-operative, and Peasant Sectors.

Development and Change 26 (2, April): 209-234.

Enríquez, Laura J. 1994. The Question of Food Security in Cuban Socialism. Berkeley, CA: International and Area Studies, University of California.

Forster, Nancy. 1989. Cuban Agricultural Productivity. In Cuban Communism, edited by I.L. Horowitz, pp. 235-255. New Brunswick, NJ: Transaction Publishers.

Kaplowitz, Michael D., and Donna Rich Kaplowitz. 1993. Cuba and the United States: Opportunities Lost and Future Potential. In Cuba's Ties to a Changing World, edited by D.R. Kaplowitz. Boulder, CO: Lynne Reinner Publishers.

Nova González, Armando. 1994. La Reorganización de la Agricultura en Cuba-Factor Clave en la Estabilización Económica. Instituto Nacional de Investigaciones Económicas, Ciudad de la Habana (May).

Roy, Joaquín. 2000. Cuba, the United States, and the Helms-Burton Doctrine - International Reactions. Gainesville, FL: University Press of Florida.

Socorro, Miguel, Luis Alemán, and Salvador Sánchez. 2001. El Cultivo Popular del Arroz en Cuba. In Transformando el Campo Cubano - Avances de la Agricultura Sostenible, edited by F. Funes, L. García, M. Bourque, N. Pérez, and P. Rosset, pp. 111-118. Ciudad de la Habana: Asociación Cubana de Técnicos Agrícolas y Forestales.

\section{Additional Information}

Below is a list of the fact sheets in this series on Cuban Agriculture. They can be accessed by clicking on the highlighted links:
- FE479 - Cuban Agriculture Before 1959: The Political and Economic Situations

- FE480 - Cuban Agriculture Before 1959: The Social Situation

- FE481 - Transformations in Cuban Agriculture After 1959

- FE482 - Overview of Cuba's Food Rationing System

- FE483 - The Issue of Food Security in Cuba

- FE484 - Acopio: Cuba's State Procurement and Distribution Agency

- FE485 - Antecedents of the Cuban Agricultural Policies of the 1990s

- FE486 - Chronology of Cuban Reform Policies with Emphasis on Agriculture, 1993-1995

- FE487 - Cuba's Basic Units of Cooperative Production

- FE488 - Cuba's Agricultural Markets

- FE489 - Environmental Deterioration and Conservation in Cuban Agriculture

- FE490 - The Potential Correlation between Natural Disasters and Cuba's Agricultural Performance 